Portland State University

PDXScholar

8-1-2012

\title{
The Lumberman's Frontier: Three Centuries of Land Use, Society, and Change in America's Forests
}

William L. Lang

Portland State University, langw@pdx.edu

Follow this and additional works at: https://pdxscholar.library.pdx.edu/hist_fac

Part of the United States History Commons

Let us know how access to this document benefits you.

Citation Details

Lang, W. L. (2012). The Lumberman's Frontier: Three Centuries of Land Use, Society, and Change in America's Forests. Pacific Historical Review, 81(3), 465.

This Book Review is brought to you for free and open access. It has been accepted for inclusion in History Faculty Publications and Presentations by an authorized administrator of PDXScholar. Please contact us if we can make this document more accessible: pdxscholar@pdx.edu. 
The Lumberman's Frontier: Three Centuries of Land Use, Society, and Change in America's Forests. By Thomas R. Cox. (Corvallis, Oregon State University Press, 2010 . xi +531 pp. $\$ 35$ paper)

The scope of The Lumberman's Frontier is impressive, covering commercial logging operations from Maine to Michigan and Wisconsin, from Georgia and the Gulf States to the Rockies and the Pacific Northwest over three centuries. The author's labor of love for more than three decades, The Lumberman's Frontier is a historical travelogue along the trail of early forest operations that brought capital, machines, and loggers to heavy stands of pine, hardwoods, and fir. It is a story of individual entrepreneurs and decidedly not a general history of American forestry or forest policies. "I try to keep the principals at center stage," the author writes in his preface, "and let them speak for themselves" (p. x). The text is laced with biographical portraits of key lumbermen in each region that outline the methods each entrepreneur applied in a highly competitive business. The overall story Thomas Cox tells is less about pillaging the forests than about the business calculations and personal skills that made each lumberman successful in very different forested landscapes. For readers who want details on the development of commercial lumber operations, this volume is a compendiumperhaps the most detailed in print-of logging methods and conditions in the working woods. It is a story informed by a triumphalist viewpoint.

Cox develops as his major theme the serial adoption of logging technology and business organization as big-scale lumber operations spread from east to west, but he also underscores innovative 
technologies and business strategies. He further argues that lumbermen's frontiers developed serially, as local usufruct timber cutting became commercial operations, from Bangor, Maine's great export operation in the early nineteenth century to the corporate, industrial deforestation of the Pacific West. Cox tends to vest the explanation for historical change in individuals and business operations rather than larger economic and social forces. Frederick Weyerhaeuser, for example, emerges as a near-heroic figure, as Cox charts his rise as mastermind of the Mississippi River Logging Company's syndication of log booms, mills, and forest properties in the Upper Midwest in the 1870s and his leap to the big conifer forests of the Pacific Northwest at the end of the century. "Weyerhauser's considerable skill in human relations," Cox writes, "softened the impact of his tunnel vision. Self-absorption may be too strong a label for this side of the man, but under whatever label, it certainly was a key element in his eventual success" (p. 188).

This book is written from a vantage point some might see as outmoded, for Cox pays little analytical attention to labor or environmental conditions in the business of cutting forests and marketing lumber. In a final chapter that feels tacked on, Cox addresses a major background question: "Whose Forests Are They?" His answer avoids evaluation of the consequences of the three-century frontier story he details in preceding chapters. The twentieth-century pursuit of a sustained-yield basis for industrial forestry, for example, is handled anecdotally, and Cox quotes a timber operator who blames the failure of sustained yield on the U.S. Forest Service. How accurate an assessment that might be is left unexamined, but the weight of Cox's detailed narrative seems to emphasize the redundancy of private enterprise deforesting America with little concern for sustainability. 